\title{
Fever induced by fluorine-containing lubricant on stainless steel tubes
}

\author{
B ÅKESSON, B HÖGSTEDT, AND S SKERFVING \\ From the Department of Occupational Medicine, University Hospital, Lund, Sweden
}

\begin{abstract}
Three subjects, all smokers, handling stainless steel tubes suffered repeated attacks of general malaise, chills, and fever lasting for several hours, mainly after gas soldering. Provocations by rubbing smoking tobacco against a tube produced similar attacks, and leucocytosis, after a few hours. The presence of fluorine on the tubes and in the febrifacient tobacco was shown. A fluorocarbon polymer lubricant was suspected of causing the attacks. Heating $\left(1000^{\circ} \mathrm{C}\right)$ of the tubes eliminated the effect.
\end{abstract}

Occupational chills and fever can result from various agents, including fumes of different metals (zinc, copper, manganese, and cadmium), fumes containing thermal decomposition products of fluorocarbon polymers, and aerosols containing proteins of microbiological origin. We report three cases of fever of occupational origin.

\section{Case histories}

In a factory manufacturing electrical equipment three men (aged 28-32 years) complained of strange, frequent attacks of fever. All three were smokers, but one had recently stopped. All three had previously been healthy; none had a history of atopy. Each attack started with a feeling of general malaise, headache, joint and muscle pains, abdominal discomfort, dry cough, chills, fulminant fever (maximum $40^{\circ} \mathrm{C}$ ) with euphoria, and ceased with an abrupt disappearance of the symptoms and the return of body temperature to normal.

All three men had handled stainless tubes made in Switzerland. The tubes were fetched from a store, cut into lengths, gas-soldered (with a solder not containing cadmium), and mounted in various machines. The attacks of fever started in 1974, shortly after the arrival of a new shipment of tubes. Tubes received earlier and later from the same producer were not associated with illness.

The attacks occurred mainly after gas-soldering of the tubes. Smokers, but not non-smokers, however,

Received 2 July 1979

Accepted 24 October 1979 had attacks simply after handling the tubes-that is, without soldering. The three workers affected were the only ones who had handled and soldered tubes of the 1974 shipment. One of the men rolled his own cigarettes, and his girl friend had an attack a few hours after smoking one of them.

\section{Provocations}

Attacks were produced experimentally: $0.5 \mathrm{~g}$ of tobacco was rubbed against $0.5 \mathrm{~m}$ of a 1974 tube. One of us smoked the tobacco in a pipe. Three to four hours later his temperature rose and after another three hours reached a maximum of $38.7^{\circ} \mathrm{C}$ (fig). This was accompanied by a corresponding increase in the leucocyte count, which reached a maximum of $18.4 \times 10^{9} / 1$. Of these, $15.3 \times 10^{9} / 1$ were polynuclear. The lymphocyte count was unaffected. The symptoms were of the same type as those reported by the workers. Auscultation showed wheezing and soft rales over the basal parts of the lungs. Dynamic spirometry showed nothing remarkable. Complement factors $\left(\mathrm{C}_{3}, \mathrm{C}_{4}, \mathrm{C}_{1} \mathrm{q}, \mathrm{C}_{1} \mathrm{~s}\right.$, and $\mathrm{C}_{1}$-esterase-inhibitor) as well as several serum and plasma coagulation and fibrinolytic factors were studied before exposure, during the attack, and 24 hours later. The complement system remained unchanged, but coagulation factor XII showed a moderate increase during the attack and factor VIII and fibrinogen a slight increase the day after, when the C-reactive protein in serum was also slightly increased.

Further similar experiments showed that heating the 1974 tubes to $1000^{\circ} \mathrm{C}$ eliminated their febrifacient 


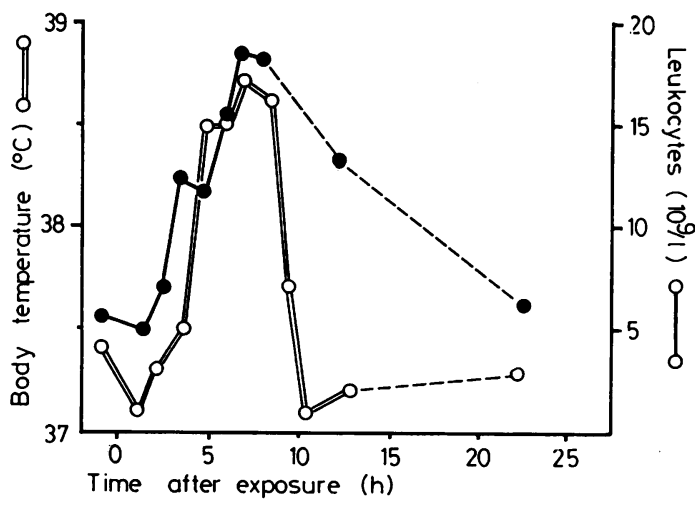

Body temperature and white blood cell count before and after smoking treated tobacco.

effect. This effect was resistant to degreasing of the tubes in a hot trichloroethylene bath.

\section{Analysis}

The symptoms resembled those of metal and polymer fume fever. Attention was therefore focused on these possible causes. $0.5 \mathrm{~g}$ of tobacco was rubbed against $0.5 \mathrm{~m}$ of different tubes. The tobacco was wetdigested, and the solution was analysed by atomic absorption spectrophotometry (table 1). Rubbing increased the chromium and nickel content from the tubes received in 1974 as well as from those received later. As the latter tubes did not provoke fever, it seems reasonable to assume that chromium and nickel can be excluded as a cause of the disease. Other metals studied did not increase significantly.

To ascertain whether the reaction was of the polymer fume fever type, we measured fluorine on the surface of the tubes (table 2). Pieces of tubes were heated to $1000^{\circ} \mathrm{C}$ in an airstream, which was bubbled through an alkaline solution. With the aid of an ionspecific electrode the solution was analysed for fluorine ions. Untreated tubes from the 1974 shipment contained large amounts of fluorine, while heated 1974 tubes, later shipments, and tubes from other manufacturers contained much smaller amounts. Determination of the fluorine content of tobacco proved much higher $(35 \mu \mathrm{g} \mathrm{F} / \mathrm{g})$ after the tobacco had been rubbed against the tube than it was before $(1 \mu \mathrm{g} \mathrm{F} / \mathrm{g})$.

\section{Discussion}

The observations made in the investigation warrant the tentative conclusion that the attacks of fever may.
Table 1 Metals in tobacco

\begin{tabular}{|c|c|c|c|}
\hline \multirow[t]{2}{*}{ Metal } & \multirow{2}{*}{$\begin{array}{l}\text { Untreated } \\
(\mu g / g)\end{array}$} & \multicolumn{2}{|c|}{ Rubbed against } \\
\hline & & $\begin{array}{l}1974 \text { tube } \\
(\mu \mathrm{g} / \mathrm{g})\end{array}$ & $\begin{array}{l}\text { Tube from later } \\
\text { shipment }(\mu \mathrm{g} / \mathrm{g})\end{array}$ \\
\hline Chromium & 1 & 14 & 34 \\
\hline Nickel & 2 & 10 & 22 \\
\hline Copper & 12 & No increase & No increase \\
\hline Zinc & 30 & , & " \\
\hline Iron & 270 & ", & , \\
\hline Manganese & 120 & , & ", \\
\hline Cadmium & 0.4 & $"$ & , \\
\hline Lead & 1 & $"$ & $"$ \\
\hline Cobalt & 1 & ", & ", \\
\hline
\end{tabular}

Table 2 Fluorine on tubes

\begin{tabular}{lr}
\hline$\mu g F / m$ \\
\hline 1974 tubes & $1500-2000$ \\
1974 tubes after heating & $60-70$ \\
Tubes from later shipment & $50-120$ \\
Tubes from other manufacturer & $50-100$ \\
\hline
\end{tabular}

have been caused by thermal decomposition products of a fluorine-containing compound on the surface of the tubes. Such products may have entered the body by inhalation of the contaminated ambient air during soldering or by cigarettes or pipe tobacco handled by contaminated fingers and afterwards decomposed and volatilised by the glow when being smoked. ${ }^{1}$

We suspect that the compound was a fluorocarbon polymer used as a drawing (lubricating) compound in the production of the tubes. Unfortunately, we could not check this possibility because the producer refused to co-operate and because the amounts of compounds were not large enough to be identified analytically.

Fever caused by fluorocarbon compounds on metal is probably not rare, and some cases have been observed elsewhere. ${ }^{2}$

It is remarkable that a dramatic fever reaction was provoked by less than $20 \mu \mathrm{g}$ of fluorine $(0.5 \mathrm{~g}$ of tobacco containing $35 \mu \mathrm{g} \mathrm{F/g}$ ). This is less than reported in earlier studies of polymer fever. ${ }^{3}$

Measurements in one of the workers of static lung volumes and the pressure-volume diagram suggested a mild pulmonary fibrosis. Frequent attacks of fever may thus not be harmless. This is also supported by post-mortem findings in one case of polymer fever. ${ }^{4}$

Complement analyses were performed by Dr AnnBritta Laurell and coagulation factors were assayed by Dr Ulla Hedner. 


\section{References}

${ }^{1}$ National Institute of Occupational Safety and Health. Criteria for a recommended standard . . . Decomposition products of fluorocarbon polymers. Washington: US Department of Health, Education and Welfare, 1977.

2 Swedish Engineering Employers' Association. Fluoroethene polymer in greases. Stockholm: Sveriges Verkstadsförening, 1976. (Report 1976-01-13.) (Report 1976-01-13 (in Swedish).)

${ }^{3}$ Clayton JW, Jr. Fluorocarbon toxicity and biological action. Fluorine Chemical Review 1967;1:197-252.

4 Williams N, Atkinson GW, Patchefsky S. Polymerfume fever: not so benign. J Occup Med 1974;16:519-22.

\section{The May 1980 issue}

\section{THE MAY 1980 ISSUE CONTAINS THE FOLLOWING PAPERS}

In-vivo determination of lead in the skeleton after occupational exposure to lead L AHLGREN, BIRGITTA HAEGER-ARONSEN, S MATTSSON, AND A SCHÜTZ

Incidence of cancer among ferrochromium and ferrosilicon workers S LANGÅRD, Aa ANDERSEN, AND B GYLSETH

Mortality and incidence of tumours among ferrochromium workers G AXELSSON, R RYLANDER, AND A SCHMIDT

Effect of kidney damage on the mobilisation of mercury by thiol-complexing agents $\mathrm{S}$ K TANDON AND L MAGOS

A neurological and biochemical study of early lead poisoning JUDITH A S ASHBY

Interaction of atopy and exposure to cotton dust in the bronchoconstrictor response $R$ N JONES, $B$ BUTCHER, Y Y HAMMAD, J E DIEM, H W GLINDMEYER, III, $S$ B LEHRER, J M HUGHES, AND H WEILL

Lung function in workers exposed to polyvinyl chloride dust C P CHIVERS, C LAWRENCE-JONES, AND G M PADDLE

Effects of exposure to slate dust in North Wales J R GLOVER, CAROL BEVAN, J E COTES, P C ELWOOD, N G HODGES, R L KELL, C R LOWE, MARGERY MCDERMOTT, AND P D OLDHAM

Mortality experience of 161 employees exposed to ethylene dibromide in two production units $M$ OTT, H C SCHARNWEBER, AND R R LANGNER

Chemical and photoelectron spectrometry analysis of the adsorption of phospholipid model membranes and red blood cell membranes on to chrysotile fibres M C JAURAND, J H THOMASSIN, P BAILlif, L MAGNE, J C TOURAY, AND J BIGNON

Pattern of accident distribution in the telecommunications industry $P$ R DAVIS AND N J SHEPPARD

Healthy worker effect in the total Finnish population $K$ VINNI AND M HAKAMA

$\mathrm{N}$-N-Dimethylformamide concentration in environmental and alveolar air in an artificial leather factory F BRUGNONE, L PERBELLINI, AND E GAFFURI

Use of a simple body-monitoring system in a pilot study on workers exposed to unsealed gamma-ray emitting material T SUMERLING

A personal dust sampler simulating variable human lung function $\mathbf{R}$ KUCHARSKI

Notes and miscellanea Carboxyhaemoglobin levels in workers in Leicestershire garages $\mathrm{C} L$ WAITE

Book reviews

Notices

Information section

Copies are still available and may be obtained from the PUBLISHING MANAGER, BRITISH MEDICAL ASSOCIATION, TAVISTOCK SQUARE, LONDON WClH 9JR, price $£ 4.25$ (USA \$9.20), including postage 